\title{
Students' Ability to Act Independently in University Studies
}

\author{
Ausra Rutkiene, Ilona Tandzegolskiene \\ Vytautas Magnus University, Lithuania
}

\begin{abstract}
Independence is a fundamental personality trait that enables people to choose aims, tools and ways of activity and communication wisely and to act actively and efficiently. Opinions vary on when (at what age) and where (in a family / education institution) a person's ability to learn and act independently should be developed most prominently (intensively). According to Linkaityte (2003), education at school is closely related to the objective to develop schoolchildren's skills to look for information. The aim working with students is to provide them with sources of information and to support individual search for information, to encourage creativity, critical thinking and independent problem solving. However, that schools have to follow their programmes and independence is not significantly emphasized. On the other hand, the main function of higher education institutions is to "prepare students for their future activity, to develop their creative strengths, critical thinking, problem solving and constructive communication skills (Lietuvos aukštasis mokslas. Baltoji knyga 1999). One of the most important abilities of an active and responsible individual, who can act independently, is self-management, i.e. the ability to plan and organize individual learning process and ability to reflect. A university research has revealed that some of the $1^{\text {st }}$ year and $4^{\text {th }}$ year social science students describe learning independence as student's participation in planning, monitoring, correcting and assessing one's own learning process and results. Emphasis is given to creativity, ability to make the right decisions in a new learning situation when putting present and new knowledge together, the search for more diverse solutions, taking responsibility for the learning process and future learning outcomes.
\end{abstract}

\section{Introduction}

A school-leaver who enters a university is treated as an adult and is considered to be an independent individual. A transition from the dependence on teachers, books and an approved programme to freedom to plan and act independently during studies is noted. Due to the relevance of the student-centred learning process, it is important to work with students, to understand their possibilities and their wish to act independently, as well as to understand their attitude towards autonomous learning and independent activity which is assumed to be an inherent part of university studies. University students get more freedom when compared to school children who are learning at school. It is important to find out how the $1^{\text {st }}$ year students understand the concept of an independent activity, how actively they tend to initiate the process of studies and how their attitude towards an independent activity changes during studies.

The manifestation of social sciences students' independent activity was chosen as the object of the research. The following methods were used in the research: analysis of literary resources and documents, written questionnaire and statistical data analysis with MS Excel and SPSS (Statistical Package for Social Sciences) version 16.0. Descriptive statistical methods and the nonparametric Mann Whitney U test were used for the statistical analysis.

\section{Manifestation of Independent Activity during University Studies}

A number of recent discussions have emphasized the need for student-centred learning at a higher education institution. Juozaitis and Jakube [6] note the importance of "the development of an independent, self-governing, responsible and constantly improving personality". According to the authors, student-centred learning is related to her/his active participation in the learning process, personal responsibility and independence. The aim is to enable a student to learn and improve one's skills independently and responsibly. According to Chene (cited from Merriam, Caffarella [10]), an independently learning individual can be described in the light of such factors as the ability to make decisions, critical thinking, the ability to clearly understand norms and limits of the community, creativity, the ability to choose proper nature of activity, to define learning aims and to select and apply tools and learning methods that help to achieve the aim.

According to Linkaityte [9], Tereseviciene et al. [18], adults take responsibility for their life, their decisions and actions. However, they also note that when they get into a learning situation, these adults immediately lose all their independence, they feel like at school, just sitting and waiting for someone to teach them. This is a paradox resulting from school 
experience. Although it is often claimed that a school helps to develop independence and critical thinking, however, that is not always the case. Some students, as well as adults, who continue their studies after a certain period, sometimes simply wait what a lecturer will say and wait to be told what to do. The experience gained at school, when a teacher often was an all-knowing authority, often comes back at a new education institution. The Law on Education of the Republic of Lithuania and characteristics of higher education studies are analysed in order to find out how the nature of independent learning / activity changes in educational institutions and in order to validate statements provided by the authors (see Table 1).

Table 1. The purpose and characteristics of educational studies in the Law on Education of the Republic of Lithuania

\begin{tabular}{|c|c|c|}
\hline Law & Purpose & Characteristics \\
\hline $\begin{array}{l}\text { The Law on } \\
\text { Education of } \\
\text { the Republic of } \\
\text { Lithuania, } \\
\text { 2011, Article } \\
\text { 11. Secondary } \\
\text { education }\end{array}$ & $\begin{array}{l}\text { The purpose } \\
\text { of secondary } \\
\text { education }\end{array}$ & 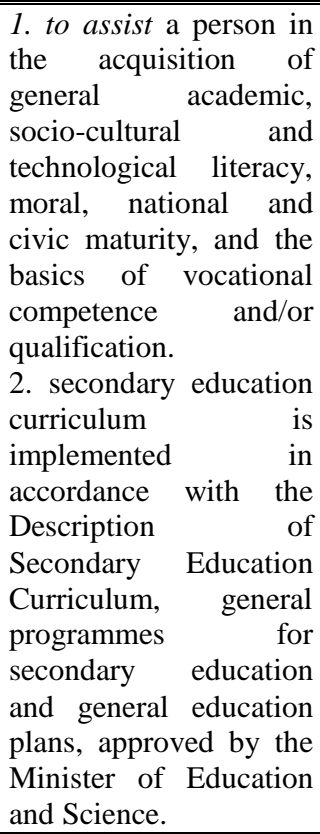 \\
\hline $\begin{array}{l}\text { The Law on } \\
\text { Education of } \\
\text { the Republic of } \\
\text { Lithuania, } \\
\text { 2011, Article } \\
\text { 14. Higher } \\
\text { education } \\
\text { studies }\end{array}$ & $\begin{array}{l}\text { The purpose } \\
\text { of higher } \\
\text { education } \\
\text { studies }\end{array}$ & $\begin{array}{l}\text { 1.to assist an individual } \\
\text { in the attainment of a } \\
\text { higher education level } \\
\text { and acquisition of a } \\
\text { respective qualification } \\
\text { as well as in preparing } \\
\text { for an active } \\
\text { professional, social and } \\
\text { cultural life. } \\
\text { 2. higher education is } \\
\text { universally available, } \\
\text { and is provided to } \\
\text { persons who have } \\
\text { attained a secondary } \\
\text { education level, have } \\
\text { entered a higher } \\
\text { education institution } \\
\text { and are able to study } \\
\text { independently. }\end{array}$ \\
\hline
\end{tabular}

(Prepared in accordance with the Law on Education of the Republic of Lithuania [8])

It can be noted from the Table 1 that the purpose of secondary education in the Law on Education of the Republic of Lithuania is to assist a person in the acquisition of general education; however, independence and its development is not mentioned in the description. Meanwhile, the purpose of higher education is to assist an individual in the attainment of higher education. However, all these individuals are already considered to be able to act autonomously during studies, i.e. learn independently. After the analysis of the current Law on Education and its provisions, regarding secondary education and higher education studies, an assumption can be drawn that the object and tools for the development of independence are not clearly defined. The above shown table indicates that at school a learner is more dependent on teachers, books, provided information, and on the approved curriculum. Article 11 (Purpose of Secondary Education) of the Law on Education of the Republic of Lithuania does not define individual's independence as one of the aims of a school. However, it could be stated here that individuals are taught independence at school while autonomous learning / independent activity is understood as search for information or independent implementation of a task given at a particular stage of learning.

The Law on Education of the Republic of Lithuania [8] divides higher education (university and non-university bachelor studies and master studies) into higher education studies (Article 14), but their purpose is the same. The fact that higher education studies provide higher education to a student who is able to act independently is emphasized. Pukeviciute [12], in accordance with Bergmann's et al. (2004) concept of learning, divides learning into three levels where the third level helps to define the concept of an ability to act independently:

1. Level 0 involves knowledge and its application in new situations.

2. Level 1 involves the stage of learning new elements of knowledge, gaining new experience. In this level, methods that help to assimilate knowledge are used and new knowledge is linked to the existing one.

3. Level 2 involves an ability to learn by thinking over the stages of learning and assessment processes, by changing traditional learning methods into contemporary methods. According to the author, this level is related to motivated regulation of one's own learning process that is oriented towards lifelong learning.

In summary, the following elements are important when pursuing independence during 
university studies: a) the ability to organise the process of learning independently, b) the ability to manage this process, c) the ability to assess the process of learning, and d) the ability to self-evaluate activities (Tanzdegolskiene, Rutkiene, Pileckaite [17]).

According to Butkiene, Kepalaite [2], "the idea of independent learning dominates psychological teaching theories that emphasize the role of thinking and interests when learning". Other authors note that the context of teaching/learning rather than learning itself has gained more importance during the recent years (Zuzeviciute, Tereseviciene [20]). The focus is on the aims of teaching/learning, internal processes that constitute and affect learning, teaching/learning results and the attitude towards learning. Research on teaching/learning is based on several different approaches: 1) behaviourist, 2) cognitive, 3) humanist and 4) constructivist (see Fig. 1).

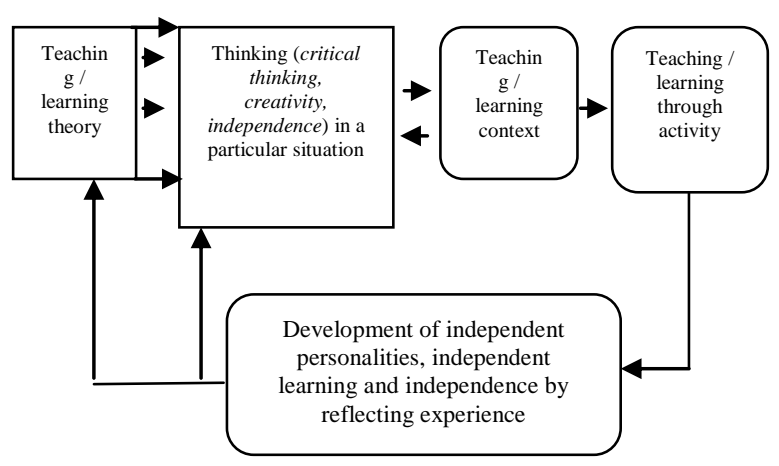

Figure 1. The impact of teaching / learning theories on the development of an independent personality, independent learning and independence, according to Ramsden 2000

(Tandzegolskiene, Pileckaite [16])

All these theories differently define a research object and human nature but all of them agree that the concept of learning has changed fundamentally. It can be stated that the process of teaching and the development of learner's independence depend on teachers' attitude towards teaching and theories that they use.

The level of independence and its characteristics have to be distinguished when reviewing teaching / learning theories (behaviourism, cognitivism, humanism and constructivism) (see Table 2). These definitions of independent learning are distinguished in accordance with theories presented by various authors (Butkiene, Kepalaite [2]; Bitinas [1]; Freire [5]; Sahlberg [14]; Muijs, Reynolds [11]; Zuzeviciute [19]; Tereseviciene et al. [18]; Carter [3], Duobliene [4]).
Table 2. Definitions of independence in different teaching/learning theories (Tandzegolskiene, Pileckaite [16])

\begin{tabular}{|l|l|l|}
\hline \multicolumn{1}{|c|}{ Theory } & \multicolumn{1}{|c|}{$\begin{array}{l}\text { Level of } \\
\text { independence }\end{array}$} & \multicolumn{1}{|c|}{ Learner } \\
\hline $\begin{array}{l}\text { Behaviourism (human's } \\
\text { external behaviour } \\
\text { changes; punishment } \\
\text { and rewards) }\end{array}$ & $\begin{array}{l}\text { Poor } \\
\text { independence }\end{array}$ & $\begin{array}{l}\text { Recipient } \\
\text { passive. } \\
\text { A learner is an } \\
\text { object while a } \\
\text { teacher is a } \\
\text { subject. learner }\end{array}$ \\
\hline $\begin{array}{l}\text { Cognitivism (processing } \\
\text { information to gain } \\
\text { results; learning through } \\
\text { "finding out") }\end{array}$ & $\begin{array}{l}\text { A needs help } \\
\text { constantly has to be } \\
\text { directed to } \\
\text { important things. }\end{array}$ \\
\hline $\begin{array}{l}\text { Humanism (a human is } \\
\text { good by nature) }\end{array}$ & $\begin{array}{l}\text { A learner is } \\
\text { free to choose }\end{array}$ & $\begin{array}{l}\text { A learner takes } \\
\text { responsibility }\end{array}$ \\
\hline $\begin{array}{l}\text { Constructivism } \\
\text { (developing, correcting } \\
\text { information, creating } \\
\text { new models) }\end{array}$ & $\begin{array}{l}\text { A learner can } \\
\text { create and test } \\
\text { her/his } \\
\text { knowledge } \\
\text { models }\end{array}$ & $\begin{array}{l}\text { A learner is free to } \\
\text { choose. }\end{array}$ \\
\hline
\end{tabular}

Definitions provided in the above table indicate that a learner is less independent in behaviourist and cognitive theories, and constantly requires encouragement and support. A learner is a passive recipient who needs to be directed to important things. In humanism and constructivism, a learner has more freedom, i.e. s/he is a responsible personality who is willing and able to act independently without encouragement and support.

It is also important to note that a schoolchild and student's manifestation of an independent activity is seen through her/his activities, through the level of independence when performing given and individually planned tasks with the help of critical thinking and creativity. The level of learner's independence can be measured through the analysis of how often and how intensively teacher and/or lecturer's help is used when performing a task, as well as through observation of learner's freedom to choose when performing a task and demonstrating the ability to apply knowledge in a simulated or natural situation.

\section{Research Rationale}

The research was performed in two stages. During the first stage in 2008, the 1st year students of social sciences from the Department of Social Sciences at Vytautas Magnus University were surveyed. 110 questionnaires were distributed; 98 of them were returned. The second stage of the research took place during the spring semester in 2012. The $4^{\text {th }}$ year students who had participated in the research in the first year of their studies were surveyed. 105 questionnaires were distributed; however, only 81 of them were returned. The total number of respondents was 179 . 
Research participants were selected using a nonprobability sampling method. The $1^{\text {st }}$ year students were chosen as recent school-leavers who can still remember their learning experience at school (where independence is minimum). The aim of the first research stage was to review how learners understand independent learning, independence during studies, as well as to identify factors that influence individual's ability to act independently. The aim of the second research stage was to reveal their attitude towards the manifestation of an independent activity at university, emphasizing changes of the attitude.

The largest part of the surveyed students is female. Only $24(13.4 \%)$ male respondents participated in the survey whereas the remaining 155 $(86.6 \%)$ of the respondents were female.

\section{Ability to Act Independently during University Studies}

Supporters of different teaching/learning theories (Butkiene, Kepalaite [2]; Bitinas [1]; Sahlberg [14]; Muijs, Reynolds [11]; Zuzeviciute [19]; Tereseviciene et al. [18]; Carter [3]) provide different definitions of independence. Some authors note that it can be teaching where a learner only has minimum freedom to define learning aims and objectives. Others believe that it could be continuous learner's encouragement to perform an independent activity and provide help. The third group of authors think that a learner is free to choose, s/he is responsible for the educational process and / or is given an opportunity to test own models of knowledge. These authors claim that a learner is independent during the process of learning, s/he is able not only to find and process information, but also to assess her/his achievements. Table 3 presents statements formulated in order to find out students' attitude towards how they understand independence during studies.

Table 3. The concept of independence during studies

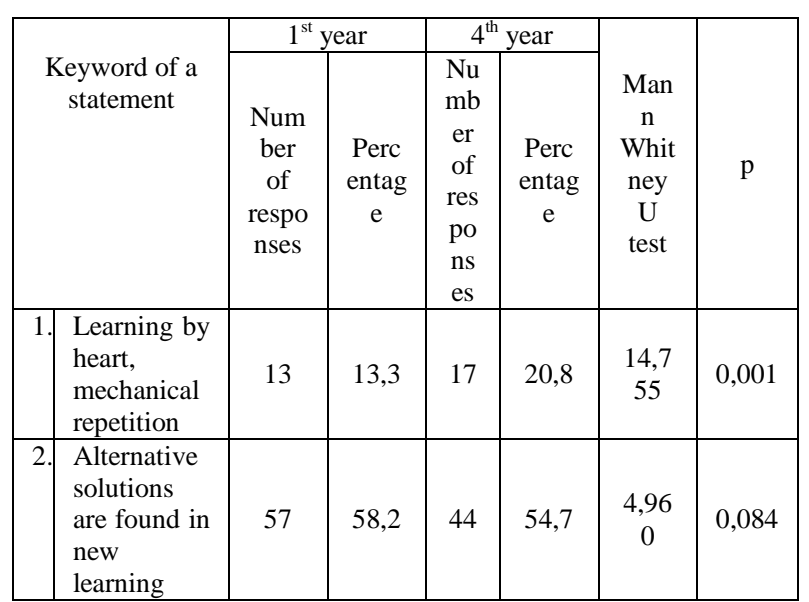

\begin{tabular}{|c|c|c|c|c|c|c|c|}
\hline & $\begin{array}{l}\text { situations } \\
\text { when new } \\
\text { and already } \\
\text { present } \\
\text { knowledge } \\
\text { is } \\
\text { coordinated }\end{array}$ & & & & & & \\
\hline 3. & $\begin{array}{l}\text { Using } \\
\text { creativity }\end{array}$ & 54 & 55,1 & 44 & 54,7 & $\begin{array}{c}1,78 \\
1\end{array}$ & 0,410 \\
\hline 4. & $\begin{array}{l}\text { Motivated } \\
\text { to learn but } \\
\text { needs } \\
\text { references } \\
\text { to master } \\
\text { certain } \\
\text { knowledge }\end{array}$ & 43 & 43,9 & 23 & 28,3 & $\begin{array}{c}3,56 \\
7\end{array}$ & 0,168 \\
\hline 5. & $\begin{array}{l}\text { Being } \\
\text { confident } \\
\text { with present } \\
\text { knowledge } \\
\text { and abilities }\end{array}$ & 48 & 49 & 47 & 58,5 & $\begin{array}{c}1,24 \\
9\end{array}$ & 0,535 \\
\hline 6. & $\begin{array}{l}\text { Being able } \\
\text { to plan own } \\
\text { learning, to } \\
\text { monitor, } \\
\text { correct and } \\
\text { assess } \\
\text { learning } \\
\text { results and } \\
\text { the process } \\
\text { itself }\end{array}$ & 77 & 78,6 & 61 & 75,5 & $\begin{array}{c}6,93 \\
8\end{array}$ & 0,031 \\
\hline
\end{tabular}

The most significant differences are noted in statements No. 1, 2 and 6. It has to be noted that students never agreed to the first statement (independent learning is learning by heart) - neither in the first year of their studies nor during the $8^{\text {th }}$ semester in their fourth year. A significantly large part of the $1^{\text {st }}$ year $(58.2 \%)$ and the $4^{\text {th }}$ year $(54.7 \%)$ students agree that the concept of independence is closely related to the second statement, i.e. independence during studies is finding alternative solutions in a new learning situation when coordinating new and already present knowledge. The difference in this case is not statistically significant $(p=0.084)$. It has to be noted that the largest part of students understand independence during studies as a possibility to plan one's own learning, monitor, correct and assess own learning results and the process itself. Both the $1^{\text {st }}$ year students $(78.6 \%)$ and the $4^{\text {th }}$ year students $(75.5 \%)$ agree to this statement. In case of the statement No. 6 , the difference is statistically significant $(\mathrm{p}=0.031)$.

In order to find out respondents' opinion of what factors could help to act independently, they were provided with 7 statements (see Table 4) that distinguish self-control, responsibility, motivation, student's experience, teaching / learning planning, the importance of learning environment and the use of skills when learning. 4 learning theories were used, including behaviourism, cognitivism, humanism and constructivism. Depending on the used theory, a learner can be presented as an independent personality, motivated and responsible for one's own learning (constructivist theory), or as 
an individual who lacks knowledge and needs help (humanist theory), or as an individual who learns through questions and answers and where teacher's / lecturer's participation in the process of learning is extremely important (behaviourist theory).

Both the $1^{\text {st }}$ year and the $4^{\text {th }}$ year students agreed that motivation and responsibility are the factors that help to act independently (see Table 4). Respondents' answers indicate that both the $1^{\text {st }}$ year and the $4^{\text {th }}$ year students almost equally distinguish responsibility as one of the most important factors of independent activity during studies: $67(68.4 \%)$ of the $1^{\text {st }}$ year students and $51(62.3 \%)$ of the $4^{\text {th }}$ year students. Motivation is also an important factor that helps to develop an ability to act independently. 83 $(84.7 \%)$ of the 1 st year students and $61(75.5 \%)$ of the $4^{\text {th }}$ year students support this statement.

Table 4. Factors that encourage independence during studies

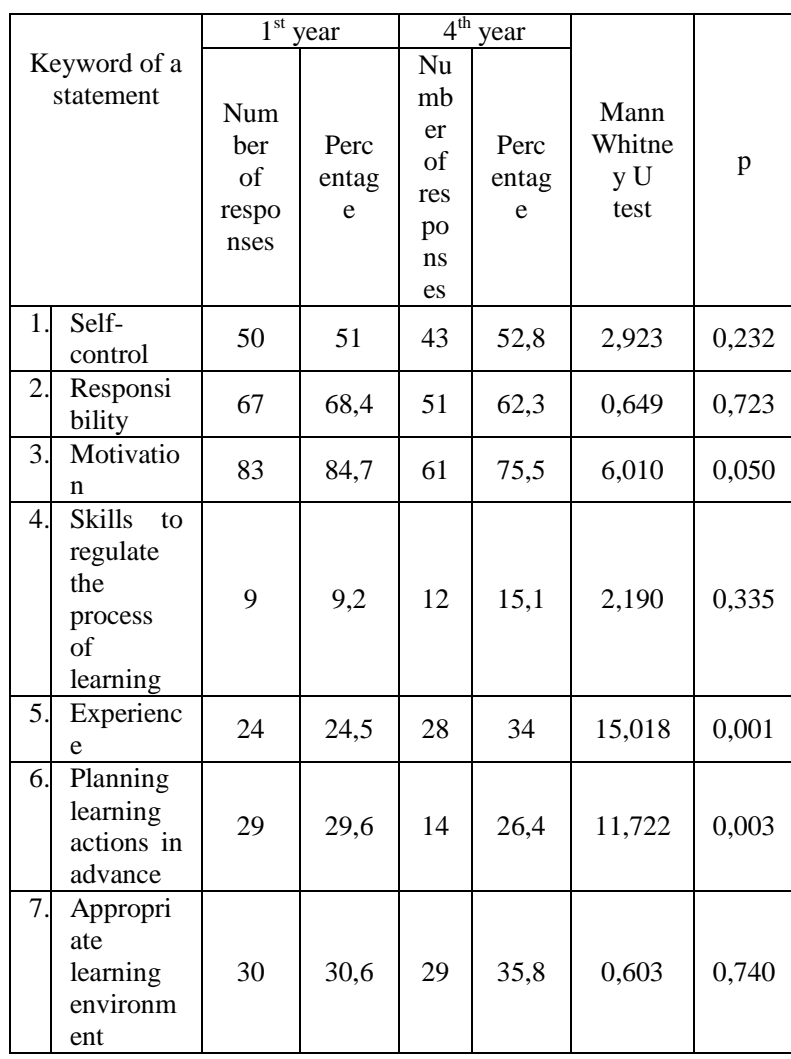

Statistically significant differences are found in the statements No. 5 and No. 6 after calculating the Mann Whitney U test value $(p=0.001, p<0.05)$. The analysis has shown that the $1^{\text {st }}$ year students value planning their learning actions in advance while the $4^{\text {th }}$ year students emphasize the value of experience.

When promoting students' independence and autonomous learning during studies, it is important for study aims and results to correspond to personal students' interests. Students should also be involved in the study process planning. All this would help to encourage students' independence and would improve their motivation to study. In order to find out what would encourage students' independence, respondents were provided with 6 statements (see Table 5).

Table 5. Activity that can encourage independence

\begin{tabular}{|c|c|c|c|c|c|c|c|}
\hline \multirow{2}{*}{\multicolumn{2}{|c|}{$\begin{array}{l}\text { Keyword of a } \\
\text { statement }\end{array}$}} & \multicolumn{2}{|c|}{$1^{\text {st }}$ year } & \multicolumn{2}{|c|}{$4^{\text {th }}$ year } & \multirow[b]{2}{*}{$\begin{array}{c}\text { Man } \\
\text { n } \\
\text { Whit } \\
\text { ney } \\
\text { U } \\
\text { test }\end{array}$} & \multirow[b]{2}{*}{$\mathrm{p}$} \\
\hline & & $\begin{array}{l}\text { Num } \\
\text { ber } \\
\text { of } \\
\text { respo } \\
\text { nses }\end{array}$ & $\begin{array}{c}\text { Perc } \\
\text { entag } \\
\text { e }\end{array}$ & $\begin{array}{c}\mathrm{Nu} \\
\mathrm{mb} \\
\mathrm{er} \\
\text { of } \\
\text { res } \\
\text { po } \\
\text { ns } \\
\text { es }\end{array}$ & $\begin{array}{l}\text { Perc } \\
\text { entag } \\
\text { e }\end{array}$ & & \\
\hline 1. & $\begin{array}{l}\text { More } \\
\text { freedom } \\
\text { and } \\
\text { responsibili } \\
\text { ty to } \\
\text { independent } \\
\text { ly make } \\
\text { decisions } \\
\text { related to } \\
\text { the process } \\
\text { of learning }\end{array}$ & 62 & 63,3 & 55 & 67,9 & $\begin{array}{c}0,51 \\
3\end{array}$ & 0,774 \\
\hline 2. & $\begin{array}{l}\text { More } \\
\text { diverse } \\
\text { learning } \\
\text { methods }\end{array}$ & 45 & 45,9 & 54 & 66 & $\begin{array}{c}7,02 \\
9\end{array}$ & 0,030 \\
\hline 3. & $\begin{array}{l}\text { Possibility } \\
\text { to prepare a } \\
\text { learning } \\
\text { plan, to set } \\
\text { learning } \\
\text { aims and } \\
\text { define } \\
\text { results } \\
\text { together } \\
\text { with a } \\
\text { lecturer }\end{array}$ & 53 & 54,1 & 43 & 52,8 & $\begin{array}{c}3,32 \\
9\end{array}$ & 0,189 \\
\hline 4. & $\begin{array}{l}\text { Possibility } \\
\text { to choose } \\
\text { forms of } \\
\text { independent } \\
\text { works } \\
\text { (paper, } \\
\text { presentation } \\
\text { essay, } \\
\text { analysis } \\
\text { etc.) }\end{array}$ & 71 & 72,4 & 40 & 49,1 & $\begin{array}{c}8,16 \\
4\end{array}$ & 0,017 \\
\hline 5 . & $\begin{array}{l}\text { Possibility } \\
\text { to discuss, } \\
\text { present own } \\
\text { opinion, } \\
\text { reveal } \\
\text { beliefs } \\
\text { without } \\
\text { being afraid } \\
\text { to be } \\
\text { criticised }\end{array}$ & 58 & 59,2 & 50 & 62,3 & $\begin{array}{c}1,93 \\
4\end{array}$ & 0,380 \\
\hline 6. & $\begin{array}{l}\text { Nothing has } \\
\text { to be } \\
\text { changed }\end{array}$ & 4 & 4,1 & 2 & 1,9 & $\begin{array}{c}1,71 \\
7\end{array}$ & 0,424 \\
\hline
\end{tabular}

Nonparametric comparison of the quantitative variable in two independent samples has revealed 
statistically significant differences that can be clearly seen after calculating the value of the Mann Whitney $\mathrm{U}$ test $(\mathrm{p}=0.001, \mathrm{p}<0.05)$. Statistically significant differences were also found for the statements No. 2 and No. 4: during their $1^{\text {st }}$ year studies respondents emphasized the possibility to choose forms of independent work themselves $(72.4 \%)$ while the $4^{\text {th }}$ year students note the importance of a possibility to choose diverse learning methods that could be used during studies $(66.0 \%)$.

In order to find out students' opinion on what teaching / learning theories prevail at university, they were given statements related to different theories: behaviourism, cognitivism, humanism and constructivism. 17 statements were prepared in accordance with the analysed learning theories. Some examples of these statements include: 1 . during studies, it is important to present, definitions, explanations and rules; 2 . when studying, it is important to focus on important material that has to be analysed, understood and evaluated; 3. during lectures, questions are raised, problems are analysed and solutions are made; 4. Students are allowed to look for answers, analyse if their answers are correct etc. individually. Respondents were asked to assess how these statements are manifested during their studies. After calculating the results, attitudes prevailing at university could be distinguished and the $1^{\text {st }}$ year and the $4^{\text {th }}$ year students' opinions could be compared (see Figure 2).

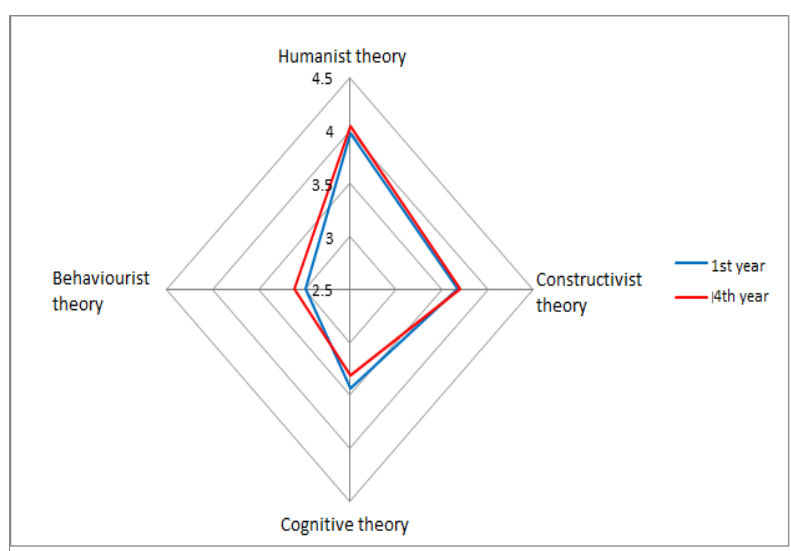

Figure 2. Attitude towards teaching / learning theories prevailing at universities (distribution by mean value)

Both the $1^{\text {st }}$ year and the $4^{\text {th }}$ year students have similar opinions about the most valued theories. Two learning theories most frequently used during studies are humanism and constructivism. Mean values of the answers have shown that the $1^{\text {st }}$ year and the $4^{\text {th }}$ year students have identical opinions, i.e. both groups state that the humanist theory largely prevails in the process of learning at university (mean values 3.98 and 4.04). The constructivist theory is also used similarly (mean values 3.67 and 3.7 ). Behaviourism and cognitivism theories are used less frequently during studies. Respondents note that the cognitivism theory is used rather often - mean values are 3.43 (the $1^{\text {st }}$ year students) and 3.31 (the $4^{\text {th }}$ year students). Only a small group of the $1^{\text {st }}$ year $(2.99)$ and $4^{\text {th }}$ year (3.11) students think that the behaviourist theory is used during university studies.

\section{Conclusion}

1. During an independent activity a student is able to make decisions, to think critically and creatively, to clearly understand norms and limits of the student community, to choose the most appropriate nature of activity independently, to define learning aims and to select the most appropriate tools and methods to achieve these aims.

2. An independent activity involves the following factors: a) an ability to organise the process of learning independently, b) an ability to assess the process of learning, and d) an ability to selfevaluate activities.

3. A part of the $1^{\text {st }}$ year and the 4 th year students define independence in learning as their student's participation in planning, monitoring, correcting and assessing one's own learning process and its results. The emphasis is on creativity and the ability to make proper decisions in a new learning environment. Students should coordinate their new and already present knowledge. They should look for diverse solutions and should take responsibility for future results.

4. The $1^{\text {st }}$ year students emphasize motivation to learn as an important factor of independent learning and believe that planning of learning actions in advance helps them to act independently during studies. Meanwhile, the $4^{\text {th }}$ year students emphasize the importance of experience. These students also note the importance of a possibility to make a plan of learning actions together with a lecturer, to individually define one's aims and planned results, to individually choose the form of independent work.

\section{References}

[1] Bitinas B. (2000). Ugdymo filosofija. Vilnius: Enciklopedis.

[2] Butkiene G., Kepalaite A. (1996). Mokymasis ir asmenybes brendimas. Vilnius: Margi raštai.

[3] Carter S. (2008). Humanism. Prieiga internetu: http://web.ebscohost.com/ehost/pdf?vid=7\&hid=112\& $\mathrm{sid}=48 \mathrm{f} 97 \mathrm{f} 8 \mathrm{c}-2 \mathrm{e} 2 \mathrm{~b}-48 \mathrm{eb}-8662-$

7e07776c1223\%40sessionmgr107. [Access date: 200901-09]. 
[4] Duobliene L. (2011). Ideologizuotos švietimo kaitos tendencijos. Vilnius: Vilniaus universitetas.

[5] Freire P. (2000). Engiamuju pedagogika. Vilnius: Tyto alba.

[6] Jakube A., Juozaitis A. (2012). Bendrujų kompetencijų ugdymas aukštojoje mokykloje. Vilnius: Vilniaus universitetas.

[7] Lietuvos aukštasis mokslas. Baltoji knyga (1999). Lietuvos Respublikos švietimo ir mokslo ministerija.

[8] Lietuvos Respublikos Švietimo istatymas (2011). Vilnius: Švietimo ir mokslo ministerija.

[9] Linkaityte G. M. (2003). Lietuvos suaugusiujų švietimo naujoves: kontekstas ir patirtis. Profesinis rengimas: tyrimai ir realijos. Nr. 6. Kaunas: VDU.

[10] Merriam S. H., Caffarella R. S. (1999) Learning in Adulthood. A Comperhensive Gude. San Francisco: Jossey - Bass.

[11] Muijs D., Reynolds D. (2005). Effective teaching. Evidence and practice. London: Sage Publications.

[12] Pukeviciute V. J. (2007) Mokymosi mokytis kompetencijos ugdymo aspektai. Acta Pedagogica Vilnensia. Vilnius.

[13] Ramsden P. (2000). Kaip mokyti aukstojoje mokykloje. Vilnius: Aidai.

[14] Sahlberg P. (2003). Kaip suprantamas mokymasis. Helsinkio universitetas.

[15] Šalkauskis S. (2005). Rastai (VIII). Vilnius: Mintis.

[16] Tandzegolskiene I., Pileckaite R. (2010). Socialinių mokslų srities studentų savarankiškos veiklos raiška universitetinese studijose. Pedagogika 97. Vilnius: Vilniaus pedagoginis universitetas.

[17] Tandzegolskiene, A. Rutkiene, R. Pileckaite (2010). Savarankiškos veiklos samprata universitetinese studijose. Profesinis rengimas: tyrimai ir realijos Nr. 19. Kaunas: VDU.

[18] Tereseviciene M., Oldroyd D., Gedviliene G. (2006).Suaugusiuju mokymasis. Kaunas: VDU.

[19] Zuzeviciute V. (2005). Suangusiuju mokymosi poreikiai. Kaunas: VDU.

[20] Zuzeviciute V., Tereseviciene M. (2007). Universitetines studijos mokymosi visa gyvenima perspektyvoje. Monografija. Kaunas: VDU. 